\title{
Usaha Meningkatkan Hasil Belajar Siswa Melalui Model Pembelajaran Kooperatif Tipe STAD Pada Materi Senyawa Karbon Turunan Alkana Di SMA Negeri 1 Syamtalira Aron
}

\author{
Munawarah \\ SMA Negeri 1 Syamtalira Aron \\ Email : munawarah.sma1@gmail.com \\ DOI : 10.32672/jsa.v7i5.1519
}

\begin{abstract}
ABSTRAK
Berdasarkan pengamatan peneliti di sekolah, pelaksanaan pembelajaran menggunakan model pembelajaran yang bervariatif sangat rendah dan guru cenderung menggunakan model konvesional pada setiap proses pembelajaran yang dilakukannya, sehingga hasil belajar siswa masih jauh dari harapan khususnya pada pelajaran kimia. Hasil pengamatan di SMA Negeri 1 Syamtalira Aron sebagian siswa belum mampu menguasai konsep senyawa karbon turunan alkana. Tujuan penelitian ini sebagai upaya meningkatkan hasil belajar siswa terhadap materi senyawa karbon turunan alkana di kelas XII SMA Negeri 1 Syamtalira Aron. Subjek penelitian ini adalah siswa kelas XII IPA 1 yang berjumlah 24 orang. Teknik pengumpulan data yang digunakan dalam penelitian ini adalah lembar observasi aktivitas siswa, lembar observasi aktivitas guru, dan tes. Penelitian terdiri dari tiga siklus. Pada siklus I siswa yang tuntas 18 orang (75\%). Siklus II siswa yang tuntas 21 orang $(87,5 \%)$, sedangkan pada siklus III siswa yang tuntas belajar 22 orang $(91,67 \%)$. Berdasarkan persentase tersebut dapat disimpulkan bahwa hasil belajar siswa pada siklus I belum mencapai ketuntasan secara klasikal, akan tetapi pada siklus II dan siklus III mencapai ketuntasan secara klasikal, karena siswa yang tuntas secara individual $\geq 85 \%$. Hasil observasi terhadap kemampuan guru mengelola pembelajaran diperoleh bahwa aktivitas guru mengelola pembelajaran dengan menggunakan model pembelajaran berada pada kategori baik dan setiap siklus mengalami peningkatan. Hasil observasi terhadap aktivitas siswa selama proses pembelajaran mengalami peningkatan, meskipun ada aktivitas yang tidak efektif pada setiap siklus, tetapi persentase aktivitasnya menuju nilai yang lebih baik.

Kata Kunci: Kooperatif Tipe STAD, Senyawa Karbon, Alkana, Siswa
\end{abstract}

\section{PENDAHULUAN}

Belajar merupakan kebutuhan hidup yang mengupayakan dirinya sendiri, karena sejak lahir manusia memiliki dorongan melangsungkan hidup dan menuju tujuan tertentu. Menurut Feronika (2008:2) mengungkapkan bahwa "Belajar adalah proses aktif siswa untuk mempelajari dan memahami konsep-konsep yang dikembangkan sendiri atau kelompok, baik mandiri maupun dibimbing”. Belajar merupakan kegiatan yang wajib dilakukan oleh setiap orang, mulai dari lahir sampai ke liang lahat tidak terkecuali baik pria maupun wanita. Selanjutnya Syah (2002:89) mengungkapkan bahwa "Belajar merupakan kegiatan yang berproses dan merupakan unsur yang sangat fundamental dalam 
Munawarah

setiap penyelenggaraan jenis dan jenjang pendidikan. Ini berarti bahwa berhasil atau gagalnya pencapaian tujuan pendidikan, sangat tergantung pada proses belajar yang dialami siswa, baik dilingkungan sekolah maupun dilingkungan keluarganya sendiri'Hal tersebut tentu saja karena ikhtiar untuk melangsungkan hidup bersumber dari dirinya, selain itu, sebagai makhluk sosial ia harus mempertahankan hidup. Demikian juga dorongan esensial dalam diri manusia, yaitu dorongan untuk tumbuh berkembang dan dorongan untuk mempertahankan diri menjelaskan alasan manusia itu belajar. Dengan belajar kualitas sumber daya manusia menjadi meningkat.

Dalam upaya peningkatan sumber daya manusia (SDM), anak merupakan sasaran prioritas pembangunan. Oleh karena itu anak-anak harus dipersiapkan dengan baik untuk melanjutkan hidup mereka. Adapun persiapan itu dilakukan melalui pendidikan. Pendidikan merupakan usaha sadar yang dilakukan guru agar siswa dapat mencapai tujuan tertentu. Peningkatan mutu pendidikan adalah menjadi tanggung jawab semua pihak yang terlibat dalam pendidikan mulai dari SD sampai Perguruan Tinggi. Guru adalah orang yang paling berperan dalam menciptakan sumber daya manusia yang berkualitas yang dapat bersaing di jaman sekarang. Guru dalam setiap pembelajaran selalu menggunakan pendekatan, strategi dan metode pembelajaran yang dapat memudahkan siswa memahami materi yang diajarkannya.

Hasil pengamatan selama peneliti mengajar, pelaksanaan pembelajaran di kelas terutama dalam penggunaan model pembelajaran yang bervariatif masih sangat rendah dan guru cenderung menggunakan model pembelajaran konvesional pada setiap pembelajaran yang dilakukannya. Hal ini mungkin disebabkan kurangnya penguasaan guru terhadap model-model pembelajaran yang ada. Padahal penguasaan terhadap model-model pembelajaran sangat diperlukan untuk meningkatkan kemampuan profesional guru. Menurut Sardiman A.M. (2007: 132), untuk menjadi guru yang profesional tidak hanya dengan modal ijazah, tetapi harus ditambah dengan kemampuan-kemampuan teknis operasional serta persepsi-persepsi filosofis, terutama yang dapat dimanfaatkan dalam kegiatan berinteraksi dengan pihak lain.

Kurikulum Tingkat Satuan Pendidikan yang diberlakukan bertujuan untuk menghasilkan lulusan yang kompeten dan cerdas sehingga dapat melanjutkan pendidikan ke jenjang yang lebih tinggi. Hal ini hanya dapat tercapai apabila proses pembelajaran yang berlangsung mampu mengembangkan seluruh potensi yang dimiliki siswa. Di samping itu kurikulum tingkat satuan pendidikan memberi kemudahan kepada guru dalam menyajikan pengalaman belajar, sesuai dengan prinsip belajar sepanjang hidup yang mengacu pada empat pilar pendidikan universal, yaitu belajar untuk mengetahui (learning to know), belajar dengan melakukan (learning to do), belajar untuk hidup dalam kebersamaan (learning to live together), dan belajar menjadi diri sendiri (learning to be).

Untuk itu guru perlu meningkatkan mutu pembelajarannya, dimulai dengan rancangan pembelajaran yang baik dengan memperhatikan tujuan, karakteristik siswa, materi yang diajarkan, dan sumber belajar yang tersedia. Kenyataannya masih banyak ditemui proses pembelajaran yang kurang berkualitas, tidak efisien dan kurang mempunyai daya tarik, bahkan cenderung membosankan, sehingga hasil belajar yang dicapai tidak optimal. Menurut Sudjana (2008:22) hasil belajar adalah "kemampuankemampuan yang dimiliki siswa setelah menerima pengalaman belajarnya". Sedangkan 
menurut Mulyasa (2009:212) Hasil belajar merupakan "Prestasi belajar peserta didik secara keseluruhan yang menjadi indikator kompetensi dasar dan derajat perubahan perilaku yang bersangkutan".

Rendahnya perolehan hasil belajar menunjukkan adanya indikasi terhadap rendahnya kinerja belajar siswa dan kemampuan guru dalam mengelola pembelajaran yang berkualitas. Untuk mengetahui mengapa prestasi siswa tidak seperti yang diharapkan, tentu guru perlu merefleksi diri untuk dapat mengetahui faktor-faktor penyebab ketidakberhasilan siswa dalam pembelajaran. Sebagai guru yang baik dan profesional, permasalahan ini tentu perlu ditanggulangi dengan segera. Hal ini sesuai dengan pendapat Ibrahim (2008:22) bahwa kemampuan guru dalam memotivasi peserta didik untuk memperoleh sesuatu yang terbaik dari proses belajar yang dijalaninya merupakan hal yang sangat mendasar.

Proses pembelajaran merupakan proses yang sistematik, artinya kegiatan belajar yang dilakukan memerlukan kemampuan dan ketrampilan dan selalu melakukan perbaikan dengan perubahan-perubahan dalam mengajar, karena itu kesiapan guru untuk berubah merupakan syarat penting yang sedang dihadapi guru sehingga diperlukan sebuah metode pembelajaran yang efektif. Hal ini sesuai dengan pernyataan Dimyati dan Mudjiono (2008: 4) bahwa pendidikan harus dipahami sebagai upaya pertolongan untuk menyingkap kekuatan psikis alami siswa.

Hal ini berarti bahwa kita tidak dapat menerapkan model pembelajaran ortodoks yang bergantung pada ucapan. Oleh karena itu, model pembelajaran yang efektif sangat dibutuhkan. Dalam penelitian ini model efektif yang dipilih adalah model pembelajaran kooperatif. Menurut Egger dan Kauchak (dalam Johar 2006:31): "Pembelajaran kooperatif merupakan suatu kumpulan strategi mengajar yang digunakan guru untuk menciptakan kondisi belajar sesama siswa. Siswa yang satu membantu siswa lainnya dalam mempelajari sesuatu".

Terdapat beberapa macam tipe pembelajaran kooperatif. Salah satunya model pembelajaran kooperatif yang sederhana dan mudah dalam penerapannya yaitu model pembelajaran kooperatif tipe STAD. Karakteristik pembelajaran menggunakan metode kooperatif tipe STAD yaitu para siswa dibagi dalam tim belajar yang terdiri atas $4-6$ orang yang berbeda-beda tingkat kemampuan akademik, jenis kelamin, dan latar belakang etniknya. Guru menyampaikan materi, lalu siswa bekerja dalam timnya masing-masing dan memastikan bahwa semua anggota kelompoknya sudah memahami materi yang disampaikan guru. Kemudian, siswa mengerjakan kuis secara individual sesuai dengan materi yang diberikan guru dan sudah didiskusikan oleh tim (Slavin, 2005). Dalam penerapan pembelajaran kooperatif tipe STAD siswa dibagi dalam kelompok-kelompok kecil yang saling bekerja sama untuk menyelesaikan tugas-tugas akademik yang diberikan dengan tujuan prestasi belajar siswa meningkat.

Pada penelitian ini peneliti akan mencoba menerapkan model pembelajaran kooperatif tipe STAD pada materi senyawa karbon turunan alkana. Materi tersebut merupakan materi pokok yang banyak menggunakan konsep sehingga apabila siswa belum mampu menguasai konsep maka dikhawatirkan akan mengalami kesulitan dalam materi selanjutnya. Hasil pengamatan di SMA Negeri 1 Syamtilara sebagian siswa belum 
Munawarah

mampu menguasai konsep senyawa karbon turunan alkana. Beberapa indikator dalam materi ini masih sulit dikuasai oleh siswa. Sebagai contoh dalam menentukan aturan senyawa karbon. Oleh karena itu peneliti tertarik mengambil materi senyawa karbon turunan alkana sebagai materi yang akan diteliti.

\section{METODE PENELITIAN}

Penelitian ini dilakukan di SMA Negeri 1 Syamtalira Aron yang dilaksanakan pada semester genap tahun pelajaran 2015/2016. Pendekatan dalam penelitian ini adalah pendekatan kuantitatif dan kualitatif, sedangkan jenis penelitiannya merupakan penelitian tindakan kelas (PTK). Subjek penelitian ini adalah siswa kelas XII IPA 1 SMA Negeri 1 Syamtalira Aron berjumlah 24 orang yang terdiri dari 4 laki-laki dan 20 orang perempuan.

Adapun teknik pengumpulan data yang digunakan dalam penelitian ini adalah: (1) soal tes, (2) lembar observasi aktivitas siswa dan guru dalam pembelajaran. Hasil observasi aktivitas siswa dianalisis menggunakan rumus persentase. Data tentang kemampuan guru dalam mengelola pembelajaran dianalisis dengan cara deskriptif yaitu menghitung nilai rata-rata setiap aspek yang diamati dalam mengelola pembelajaran. Data hasil belajar siswa dianalisis secara deskriptif untuk menentukan ketuntasan hasil belajar. Penelitian dilakukan dalam tiga siklus. Dengan tahapan meliputi perencanaan tindakan, pelaksanaan tindakan, observasi dan refleksi.

\section{HASIL PENELITIAN DAN PEMBAHASAN Deskripsi Prasiklus}

Proses pembelajaran terhadap materi senyawa karbon turunan alkana yang dilakukan pada prasiklus masih menggunakan model pembelajaran konvensional. Hasil tes prasiklus dapat diketahui bahwa dari 24 siswa yang mengikuti tes prasiklus, 17 siswa tidak tuntas dalam pembelajaran yaitu nilai yang diperoleh kurang dari KKM yaitu 76. Jika dipersentasekan siswa yang tidak tuntas belajar pada pra siklus yaitu sebesar $70,83 \%$. Berdasarkan hal tersebut perlu dilakukan suatu tindakan dengan menerapkan model pembelajaran kooperatif tipe STAD pada materi senyawa karbon turunan alkana. Adapun tindakan yang dilakukan terdiri dari 3 siklus. Dalam setiap siklus selain melihat ketuntasan belajar siswa juga diobservasi aktivitas belajar siswa dan aktivitas guru mengelola pembelajaran dengan menggunakan lembar observasi yang telah disediakan.

\section{Siklus I}

\section{Tahap perencanaan Siklus I}

Pada tahap perencanaan ini, kegiatan yang peneliti lakukan adalah: (1) melakukan refleksi awal terhadap materi struktur senyawa karbon, (2) menyusun RPP untuk materi struktur senyawa karbon, (3) menyusun lembar kerja siswa, (4) menyusun instrumen tes, (5) menyusun lembar observasi aktivitas siswa dan guru.

\section{Tahap Tindakan Siklus I}

Pelaksanaan tindakan dilakukan sesuai dengan jadwal mata pelajaran yang telah disusun untuk kelas XII IPA 1 di SMA Negeri 1 Syamtalira Aron. Proses pembelajaran dilakukan dengan menggunakan model pembelajaran kooperatif tipe STAD. 


\section{Tahap Observasi Siklus I}

\section{Observasi Aktivitas siswa}

Adapun hasil observasi aktivitas siswa diperlihatkan pada tabel di bawah ini:

Tabel 1. Data Aktivitas Siswa pada Siklus I

\begin{tabular}{|l|c|c|c|}
\hline \multicolumn{1}{|c|}{ Aspek Pengamatan Aktivitas Siswa } & \multirow{2}{*}{ RPP I } & \multicolumn{2}{|c|}{ Persentase Kesesuaian (P) } \\
\cline { 3 - 4 } & & Waktu Ideal & Toleransi \\
\hline Mendengar/memperhatikan penjelasan guru/teman & 7,29 & $13 \%$ & $7 \% \leq \mathrm{P} \leq 18 \%$ \\
\hline Membaca/memahami masalah kontekstual di LKS & 10,42 & $10 \%$ & $5 \% \leq \mathrm{P} \leq 15 \%$ \\
\hline Menyelesaikan masalah atau menemukan solusi pemecahan masalah & 26,04 & $27 \%$ & $22 \% \leq \mathrm{P} \leq 32 \%$ \\
\hline $\begin{array}{l}\text { Membandingkan hasil temuan diskusi kelompok dengan hasil diskusi } \\
\text { Kelompoknya }\end{array}$ & 27,08 & $30 \%$ & $25 \% \leq \mathrm{P} \leq 35 \%$ \\
\hline Bertanya/menyampaikan pendapat/ide kepada guru atau teman sekelompok & 15,26 & $10 \%$ & $5 \% \leq \mathrm{P} \leq 15 \%$ \\
\hline $\begin{array}{l}\text { Menarik kesimpulan suatu konsep yang ditemukan atau suatu prosedur yang } \\
\text { dikerjakan }\end{array}$ & 8,33 & $10 \%$ & $5 \% \leq \mathrm{P} \leq 15 \%$ \\
\hline Perilaku yang tidak relevan dengan KBM & 7,29 & $0 \%$ & $0 \% \leq \mathrm{P} \leq 5 \%$ \\
\hline
\end{tabular}

Berdasarkan tabel di atas diperoleh bahwa aktivitas bertanya/menyampaikan pendapat/ide kepada guru atau teman sekelompok dan perilaku yang tidak relevan dengan KBM belum efektif dengan persentase masing-masing aktivitas sebesar 15,26\% dan 7,29\%. Aktivitas yang diamati tersebut masih berada diluar tolerasi yang diberikan, sedangkan aktivitas siswa yang lain sudah efektif.

\section{Observasi Aktivitas Guru selama Siklus I}

Data aktivitas guru dalam mengelola pembelajaran dengan menggunakan model pembelajaran STAD terhadap materi struktur senyawa karbon pada siklus I. Berdasarkan hasil pengamatan terhadap aktivitas guru pada siklus I, diperoleh bahwa rata-rata aktivitas guru selama pembelajaran siklus I sebesar 3,62. Dengan demikian rata-rata aktivitas guru pada siklus I berada pada kategori baik sesuai dengan kriteria aktivitas guru mengelola pembelajaran. Berdasarkan lembar observasi aktivitas guru mengelola pembelajaran, ada beberapa indikator yang belum memperoleh nilai terbaik. Berdasarkan hasil pengamatan dapat diperhatikan ada enam indikator yang belum memperoleh nilai 4. Oleh sebab itu, untuk siklus II harus ditingkatkan lagi indikator-indikator tersebut, sehingga diperoleh nilai maksimal.

\section{Hasil Tes Siswa pada Siklus I}

Hasil tes siswa siklus I dapat dilihat pada tabel berikut.

Tabel 3. Hasil Tes Siklus I

\begin{tabular}{|c|c|c|c|c|c|c|c|c|c|}
\hline No & Kode Siswa & Nilai & Tuntas & Tidak Tuntas & No & Kode Siswa & Nilai & Tuntas & Tidak Tuntas \\
\hline 1 & Siswa-1 & 79 & $\sqrt{t}$ & & 13 & Siswa-13 & 76 & $\sqrt{t}$ & \\
\hline 2 & Siswa-2 & 80 & $\sqrt{7}$ & & 14 & Siswa-14 & 78 & $\sqrt{ }$ & \\
\hline 3 & Siswa-3 & 45 & & $\sqrt{f}$ & 15 & Siswa-15 & 76 & $\sqrt{ }$ & \\
\hline 4 & Siswa-4 & 85 & $\sqrt{8}$ & & 16 & Siswa-16 & 82 & $\sqrt{f}$ & \\
\hline 5 & Siswa-5 & 76 & $\sqrt{t}$ & & 17 & Siswa-17 & 80 & $\sqrt{t}$ & \\
\hline 6 & Siswa-6 & 77 & $\sqrt{ }$ & & 18 & Siswa-18 & 63 & & $\sqrt{t}$ \\
\hline 7 & Siswa-7 & 90 & $\sqrt{ }$ & & 19 & Siswa-19 & 69 & & $\sqrt{ }$ \\
\hline 8 & Siswa-8 & 60 & & $\sqrt{ }$ & 20 & Siswa-20 & 45 & & $\sqrt{t}$ \\
\hline
\end{tabular}


Munawarah

\begin{tabular}{|c|l|l|l|l|l|l|l|l|l|}
\hline 9 & Siswa-9 & 87 & $\sqrt{ }$ & & 21 & Siswa-21 & 56 & & $\checkmark$ \\
\hline 10 & Siswa-10 & 85 & $\sqrt{ }$ & & 22 & Siswa-22 & 85 & $\sqrt{ }$ & \\
\hline 11 & Siswa-11 & 80 & $\sqrt{ }$ & & 23 & Siswa-23 & 80 & $\sqrt{ }$ & \\
\hline 12 & Siswa-12 & 81 & $\checkmark$ & & 24 & Siswa-24 & 83 & $\sqrt{ }$ & \\
\hline
\end{tabular}

Dari keterangan tabel di atas, dapat diketahui bahwa dari 24 siswa yang mengikuti tes siklus I, 18 siswa tuntas dalam pembelajaran yaitu nilai yang diperoleh lebih dari KKM. Jika dipersentasekan siswa yang tuntas belajar pada siklus I yaitu sebesar $75 \%$. Berdasarkan persentase tersebut dapat disimpulkan bahwa pembelajaran pada siklus I belum mencapai ketuntasan secara klasikal, karena siswa yang tuntas secara individual belum mencapai $85 \%$.

\section{Tahap Refleksi Siklus I}

Berdasarkan hasil observasi dapat diperhatikan bahwa setiap akhir siklus dilaksanakan refleksi tindakan yang didasarkan pada hasil observasi, dan catatan lapangan. Refleksi dilakukan untuk menentukan apakah tindakan pada siklus I berhasil atau belum. Berdasarkan analisis data pengamatan yang dilakukan oleh observer terhadap aktivitas guru dalam kategori "cukup" tetapi pengamatan terhadap aktivitas siswa menunjukkan taraf keberhasilan dalam kategori "aktif", karena dari 7 kategori pengamatan terhadap aktivitas siswa, hanya 2 aktivitas yang belum efektif. Jadi dapat dikatakan bahwa pada tindakan siklus I siswa belum sepenuhnya memenuhi indikator, sehingga pada tindakan siklus II diharapkan siswa lebih termotivasi agar semua indikator dalam aspek model pembelajaran kooperatif tipe STAD dapat dikuasai.

Peneliti menyimpulkan dalam tindakan siklus I bahwa proses adaptasi dan sosialisasi sudah baik meskipun masih ada beberapa siswa yang masih malu dan ragu untuk mengemukakan pendapatnya, hal ini mungkin disebabkan karena mereka masih belum terbiasa dengan model pembelajaran kooperatif tipe STAD, diantara anggota kelompok terkadang masih ada yang menganggap remeh pendapat yang diutarakan oleh anggota kelompok lain, siswa masih malu bertanya jika mereka tidak bisa, dan siswa kurang memperhatikan petunjuk dari peneliti.

Dalam tindakan selanjutnya peneliti mencoba untuk lebih memotivasi siswa untuk mengutarakan pendapatnya secara lisan dan juga menekankan betapa pentingnya anggota kelompok untuk saling belajar, saling berbagi, saling memberi, dan saling menerima pendapat orang lain, karena keberhasilan kelompok tergantung pada keaktifan, dan kekompakan setiap anggota dalam kelompok tersebut.

\section{Siklus II}

\section{Tahap Perencanaan Siklus II}

Pada tahap perencanaan ini, kegiatan yang peneliti lakukan adalah: (1) menyusun rencana pelaksanaan pembelajaran siklus II tentang materi tatanama dan isomer senyawa karbon, (2) menyusun lembar kerja siswa, (3) menyusun instrumen tes, (4) menyusun lembar observasi aktivitas siswa dan guru.

\section{Tahap Tindakan Siklus II}

Pelaksanaan tindakan siklus II terdiri dari 2 kali pertemuan. Proses pembelajaran yang dilakukan dengan menggunakan model pembelajaran kooperatif tipe STAD. 632 
Pembelajaran pada siklus II ini merupakan hasil perbaikan jika pada siklus I ada kelemahan baik berdasarkan hasil tes, hasil observasi, maupun catatan lapangan.

\section{Tahap Observasi Siklus II}

\section{Observasi Aktivitas Siswa Selama Pembelajaran}

Hasil observasi aktivitas siswa disajikan pada tabel berikut.

Tabel 3. Aktivitas Siswa pada Siklus II

\begin{tabular}{|c|l|c|c|c|c|c|}
\hline No & \multicolumn{1}{|c|}{ Aspek Pengamatan Aktivitas Siswa } & RPP II & RPP III & Rata-rata & \multicolumn{2}{|c|}{ Persentase kesesuaian (P) } \\
\cline { 5 - 7 } & & & & Waktu ideal & Toleransi 5\% \\
\hline 1 & $\begin{array}{l}\text { Mendengarkan/memperhatikan penjelasan } \\
\text { guru/teman }\end{array}$ & 9,38 & 9,38 & 9,38 & $13 \%$ & $7 \% \leq \mathrm{P} \leq 18 \%$ \\
\hline 2 & Membaca/memahami informasi di LKS & 13,54 & 13,54 & 13,54 & $10 \%$ & $5 \% \leq \mathrm{P} \leq 15 \%$ \\
\hline 3 & $\begin{array}{l}\text { Membuat soal sesuai dengan informasi yang } \\
\text { diberikan dan menjawabnya }\end{array}$ & 28,12 & 27,08 & 27,6 & $27 \%$ & $22 \% \leq \mathrm{P} \leq 32 \%$ \\
\hline 4 & $\begin{array}{l}\text { Mengemukakan soal yang dibuatnya atau } \\
\text { menjawab soal dari kelompok lain }\end{array}$ & 21,88 & 22,92 & 22,4 & $30 \%$ & $25 \% \leq \mathrm{P} \leq 35 \%$ \\
\hline 5 & $\begin{array}{l}\text { Bertanya atau menyampaikan pendapat kepada } \\
\text { guru atau temannya }\end{array}$ & 10,42 & 11,46 & 10,94 & $10 \%$ & $5 \% \leq \mathrm{P} \leq 15 \%$ \\
\hline 6 & $\begin{array}{l}\text { Menarik kesimpulan suatu konsep atau prosedur } \\
\text { yang sedang dipelajari }\end{array}$ & 9,38 & 10,42 & 9,9 & $10 \%$ & $5 \% \leq \mathrm{P} \leq 15 \%$ \\
\hline 7 & Perilaku yang tidak relevan dengan pembelajaran & 7,29 & 5,21 & 6,25 & $0 \%$ & $0 \% \leq \mathrm{P} \leq 5 \%$ \\
\hline
\end{tabular}

Pada siklus II dilakukan dua kali observasi yaitu pada pertemuan pertama dan pertemuan kedua. Observasi dilakukan pada saat siswa mengikuti pembelajaran dengan menggunakan lembar observasi aktivitas siswa yang telah dibuat pada tahap perencanaan siklus II. Pada siklus II aktivitas yang tidak efektif yaitu aktivitas perilaku yang tidak relevan dengan pembelajaran dan aktivitas mengemukakan soal yang dibuatnya atau menjawab soal dari kelompok lain masing-masing persentase rata-ratanya $22,4 \%$ dan $6,25 \%$.

\section{Observasi Aktivitas Guru Selama Pembelajaran Siklus II}

Berdasarkan hasil pengamatan terhadap aktivitas guru pada siklus II, diperoleh bahwa rata-rata aktivitas guru selama pembelajaran siklus II sebesar 3,82. Jika dibandingkan dengan siklus I, aktivitas guru pada siklus II mengalami sedikit peningkatan yaitu dari 3,62 menjadi 3,82. Dengan demikian rata-rata aktivitas guru pada siklus II juga berada pada kategori baik sesuai dengan kriteria aktivitas guru mengelola pembelajaran. Pada siklus II indikator yang mengalami peningkatan yaitu indikator menyampaikan tujuan pembelajaran dan indikator memotivasi siswa. Kedua indikator tersebut mengalami peningkatan dari skor 3 menjadi 4. Berdasarkan lembar observasi aktivitas guru, dapat dilihat bahwa ada 3 indikator lagi yang masih memperoleh skor 3. Hal ini perlu diperbaiki untuk siklus III.

\section{Hasil Tes Siswa pada Siklus II}

Hasil tes siswa siklus II dapat dilihat pada tabel berikut.

Tabel 5. Hasil Tes Siklus II

\begin{tabular}{|l|l|l|l|l|l|l|l|l|l|}
\hline No & Kode Siswa & Nilai & Tuntas & Tidak Tuntas & No & Kode Siswa & Nilai & Tuntas & Tidak Tuntas \\
\hline
\end{tabular}


Munawarah

\begin{tabular}{|c|c|c|c|c|c|c|c|c|c|}
\hline 1 & Siswa-1 & 55 & & $\sqrt{t}$ & 13 & Siswa-13 & 76 & $\sqrt{ }$ & \\
\hline 2 & Siswa-2 & 80 & $\sqrt{ }$ & & 14 & Siswa-14 & 90 & $\sqrt{t}$ & \\
\hline 3 & Siswa-3 & 77 & $\sqrt{ }$ & & 15 & Siswa-15 & 78 & $\sqrt{ }$ & \\
\hline 4 & Siswa-4 & 76 & $\sqrt{ }$ & & 16 & Siswa-16 & 85 & $\sqrt{8}$ & \\
\hline 5 & Siswa-5 & 85 & $\sqrt{ }$ & & 17 & Siswa-17 & 80 & $\sqrt{f}$ & \\
\hline 6 & Siswa-6 & 80 & $\sqrt{ }$ & & 18 & Siswa-18 & 80 & $\sqrt{8}$ & \\
\hline 7 & Siswa-7 & 79 & $\sqrt{ }$ & & 19 & Siswa-19 & 85 & $\sqrt{f}$ & \\
\hline 8 & Siswa-8 & 60 & & $\sqrt{ }$ & 20 & Siswa-20 & 77 & $\sqrt{ }$ & \\
\hline 9 & Siswa-9 & 81 & $\sqrt{7}$ & & 21 & Siswa-21 & 80 & $\sqrt{ }$ & \\
\hline 10 & Siswa-10 & 80 & $\sqrt{ }$ & & 22 & Siswa-22 & 80 & $\sqrt{7}$ & \\
\hline 11 & Siswa-11 & 78 & $\sqrt{ }$ & & 23 & Siswa-23 & 84 & $\sqrt{ }$ & \\
\hline 12 & Siswa-12 & 85 & $\sqrt{ }$ & & 24 & Siswa-24 & 70 & & $\sqrt{ }$ \\
\hline
\end{tabular}

Dari keterangan tabel di atasdapat diketahui bahwa dari 24 siswa yang mengikuti tes siklus II, 21 siswa tuntas. Jika dipersentasekan siswa yang tuntas belajar pada siklus II yaitu sebesar $87,5 \%$. Jika dibandingkan hasil belajar siklus I, hasil belajar pada siklus II mengalami peningkatan. Berdasarkan persentase tersebut dapat disimpulkan bahwa pembelajaran pada siklus II mencapai ketuntasan secara klasikal, karena $\geq 85 \%$ siswa tuntas secara individual.

\section{Tahap Refleksi Siklus II}

Adapun keberhasilan dan kelemahan yang terjadi pada siklus II adalah sebagai berikut: keberhasilan yang dicapai pada siklus II adalah hasil belajar siswa mencapai ketuntasan secara klasikal, rata-rata aktivitas guru dalam mengelola pembelajaran baik dan mengalami peningkatan, dan indikator aktivitas siswa mengikuti pembelajaran belum semua aktif.

\section{Siklus III}

\section{Tahap Perencanaan Siklus III}

Pada tahap perencanaan ini, kegiatan yang peneliti lakukan adalah: (1) menyusun rencana pelaksanaan pembelajaran siklus III tentang materi identitas dan kegunaan senyawa karbon, (2) menyusun lembar kerja siswa, (3) menyusun instrumen tes, (4) menyusun lembar observasi aktivitas siswa dan guru.

\section{Tahap Tindakan Siklus III}

Pelaksanaan tindakan siklus III terdiri dari satu kali pertemuan, Pembelajaran dilakukan dengan menggunakan model pembelajaran kooperatif tipe STAD. Pembelajaran siklus III ini merupakan perbaikan dari proses pembelajaran pada siklus II.

\section{Tahap Observasi Siklus III}

\section{Observasi Aktivitas Siswa Selama Pembelajaran}

Hasil observasi aktivitas siswa disajikan pada tabel berikut.

Tabel 6. Aktivitas Siswa pada Siklus III

\begin{tabular}{|c|c|c|c|c|}
\hline \multirow{2}{*}{ No } & Aspek pengamatan aktivitas siswa & \multirow{2}{*}{ RPP IV } & \multicolumn{2}{|c|}{ Persentase kesesuaian (P) } \\
\cline { 4 - 5 } & & & Waktu ideal & Toleransi 5\% \\
\hline 1 & Mendengarkan/memperhatikan penjelasan guru/teman & 7,29 & $13 \%$ & $7 \% \leq \mathrm{P} \leq 18 \%$ \\
\hline 2 & Membaca/memahami informasi di LKS & 14,58 & $10 \%$ & $5 \% \leq \mathrm{P} \leq 15 \%$ \\
\hline
\end{tabular}




\begin{tabular}{|c|l|c|c|c|}
\hline 3 & $\begin{array}{l}\text { Membuat soal sesuai dengan informasi yang diberikan dan } \\
\text { menjawabnya }\end{array}$ & 29,17 & $27 \%$ & $22 \% \leq \mathrm{P} \leq 32 \%$ \\
\hline 4 & $\begin{array}{l}\text { Mengemukakan soal yang dibuatnya atau menjawab soal dari } \\
\text { kelompok lain }\end{array}$ & 25 & $30 \%$ & $25 \% \leq \mathrm{P} \leq 35 \%$ \\
\hline 5 & Bertanya atau menyampaikan pendapat kepada guru atau temannya & 11,46 & $10 \%$ & $5 \% \leq \mathrm{P} \leq 15 \%$ \\
\hline 6 & $\begin{array}{l}\text { Menarik kesimpulan suatu konsep atau prosedur yang sedang } \\
\text { dipelajari }\end{array}$ & 7,29 & $10 \%$ & $5 \% \leq \mathrm{P} \leq 15 \%$ \\
\hline 7 & Perilaku yang tidak relevan dengan pembelajaran & 5,21 & $0 \%$ & $0 \% \leq \mathrm{P} \leq 5 \%$ \\
\hline
\end{tabular}

Berdasarkan tabel di atas dapat dilihat bahwa rata-rata persentase aktivitas siswa pada siklus III sudah lebih baik jika dibandingkan dengan siklus II. Pada siklus III aktivitas siswa yang belum efektif hanya aktivitas perilaku yang tidak relevan dengan pembelajaran yaitu sebesar 5,21. Walaupun tidak efektif, namun persentasenya menuju kearah yang lebih baik yaitu menuju toleransi waktu yang diberikan. Dengan demikian dapat disimpulkan bahwa secara umum aktivitas siswa pada siklus III sudah efektif.

\section{Observasi Aktivitas Guru Selama Pembelajaran Siklus III}

Berdasarkan hasil pengamatan terhadap aktivitas guru pada siklus III, diperoleh bahwa rata-rata aktivitas guru selama pembelajaran siklus III sebesar 3,87. Dengan demikian rata-rata aktivitas guru pada siklus III berada pada kategori baik sesuai dengan kriteria aktivitas guru mengelola pembelajaran. Aktivitas guru untuk siklus III mengalami peningkatan jika dibandingkan dengan siklus II. Pada siklus III indikator yang mengalami peningkatan yaitu indikator membimbing dan mengarahkan kelompok dalam memecahkan masalah sehingga dapat menemukan pengertian dari materi. Indikator tersebut mengalami peningkatan dari skor 3 menjadi 4.

\section{Hasil Tes Siswa pada Siklus III}

Hasil tes siswa siklus III dapat dilihat pada tabel berikut.

Tabel 7. Hasil Tes Siklus III

\begin{tabular}{|c|l|c|c|c|c|c|c|c|c|}
\hline No & Kode Siswa & Nilai & Tuntas & Tidak Tuntas & No & Kode Siswa & Nilai & Tuntas & Tidak Tuntas \\
\hline 1 & Siswa-1 & 55 & & $\sqrt{ }$ & 13 & Siswa-13 & 76 & $\checkmark$ & \\
\hline 2 & Siswa-2 & 80 & $\sqrt{ }$ & & 14 & Siswa-14 & 80 & $\checkmark$ & \\
\hline 3 & Siswa-3 & 85 & $\sqrt{ }$ & & 15 & Siswa-15 & 78 & $\checkmark$ & \\
\hline 4 & Siswa-4 & 78 & $\sqrt{ }$ & & 16 & Siswa-16 & 85 & $\checkmark$ & \\
\hline 5 & Siswa-5 & 80 & $\checkmark$ & & 17 & Siswa-17 & 80 & $\checkmark$ & \\
\hline 6 & Siswa-6 & 80 & $\checkmark$ & & 18 & Siswa-18 & 80 & $\checkmark$ & \\
\hline 7 & Siswa-7 & 85 & $\checkmark$ & & 19 & Siswa-19 & 80 & $\checkmark$ & \\
\hline 8 & Siswa-8 & 60 & & $\checkmark$ & 20 & Siswa-20 & 77 & $\checkmark$ & \\
\hline 9 & Siswa-9 & 80 & $\sqrt{ }$ & & 21 & Siswa-21 & 85 & $\checkmark$ & \\
\hline 10 & Siswa-10 & 80 & $\sqrt{ }$ & & 22 & Siswa-22 & 82 & $\checkmark$ & \\
\hline 11 & Siswa-11 & 90 & $\sqrt{ }$ & & 23 & Siswa-23 & 76 & $\checkmark$ & \\
\hline 12 & Siswa-12 & 84 & $\sqrt{ }$ & & 24 & Siswa-24 & 86 & $\checkmark$ & \\
\hline
\end{tabular}

Berdasarkan tabel di atas dapat diperhatika bahwa siswa yang tuntas belajar 22 orang dan jika dipersentasekan yaitu 91,67\%. Jika dibandingkan hasil belajar pada siklus sebelumnya, hasil belajar pada siklus III mengalami peningkatan. Berdasarkan persentase 
Munawarah

tersebut dapat disimpulkan bahwa pembelajaran pada siklus III mencapai ketuntasan secara klasikal, karena $\geq 85 \%$ siswa telah tuntas secara individual.

\section{Tahap Refleksi Siklus III}

Keberhasilan yang dicapai pada siklus III adalah hasil belajar siswa mencapai ketuntasan secara klasikal yaitu 91,67\%, rata-rata aktivitas guru dalam mengelola pembelajaran baik dan mengalami peningkatan, sedangkan persentase rata-rata aktivitas siswa mengikuti pembelajaran umumnya sudah aktif. Hasil observasi terhadap hasil belajar siswa, aktivitas guru, dan hasil observasi aktivitas siswa pada siklus III mengalami peningkatan jika dibandingkan dengan siklus sebelumnya.

\section{PENUTUP}

\section{Simpulan}

Berdasarkan hasil penelitian yang telah diuraikan, maka simpulan dalam penelitian ini yaitu 1) ktivitas siswa selama proses pembelajaran mengalami peningkatan, meskipun ada aktivitas yang tidak aktif pada setiap siklus, tetapi persentase aktivitasnya menuju nilai yang lebih baik, 2) aktivitas guru mengelola pembelajaran dengan menggunakan model pembelajaran berada pada kategori baik dan setiap siklus mengalami peningkatan, dan 3) hasil belajar siswa pada siklus I belum mencapai ketuntasan secara klasikal, akan tetapi pada siklus II dan siklus III mencapai ketuntasan secara klasikal, karena siswa yang tuntas secara individual $\geq 85 \%$.

\section{DAFTAR PUSTAKA}

A.M, Sardiman. 2007. Interaksi \& Motivasi Belajar Mengajar. Jakarta : PT Grafindo Persada.

Dimyati dan Mudjiono. 2008. Belajar dan Pembelajaran. Jakarta: PT. Rineka Cipta. Feronika, Tonih, dkk. 2008. Strategi Pembelajaran Kimia, Jakarta: FITK UIN.

Ibrahim, Amin. 2008. Teori dan Konsep Pelayanan Publik Serta Implementasinya. Jakarta: Mandar Maju.

Johar, Rahmah dkk. 2006. Strategi Belajar Mengajar (Bahan Ajar). Banda Aceh: FKIP Unsyiah.

Mulyasa, E. 2009. Implementasi Kurikulum Tingkat Satuan Pendidikan. Jakarta: Bumi Aksara.

Slavin, Robert. 2005. Cooperative Learning, Theory, research and practice. Bosto: Allyn and Bacon Publicer.

Sudjana, Nana. 2008. Penilaian Hasil Proses Belajar Mengajar. Bandung: Remaja rosdakarya.

Syah, Muhibbin. 2002. Psikologi Pendidikan dengan Pendidikan Baru. Bandung; PT Remaja Rosdakarya. 